\title{
SMALL TOWN DEVELOPMENT IN PERIPHERAL AREAS
}

\author{
Réka HORECZKI ${ }^{\mathrm{a}}$, Ildikó EGYED ${ }^{\mathrm{b}}$
}

\author{
a Institute for Regional Studies, Centre for Economic and Regional Studies; Papnövelde u. 22., H-7621 \\ Pécs, Hungary; horeczki.reka@krtk.hu \\ ${ }^{\mathrm{b}}$ Institute for Regional Studies, Centre for Economic and Regional Studies; Papnövelde u. 22., H-7621 \\ Pécs, Hungary; egyed.ildiko@krtk.hu
}

Cite this article: Horeczki, R., Egyed, I. (2021). Small town development in peripheral areas. Deturope, 13(2): $52-65$.

\begin{abstract}
The objective of the study is to examine the correspondence between city status and city identity and the factors explaining the spectacularly large number of small cities in Hungary. A further aim is to explore the positive or negative impacts of the acquisition of city status on the development of the urban network. The study, using a historical approach, aimed to identify the key enabling factors of the transformation of small towns into cities. This was achieved through the qualitative assessment of specific properties of the urban micro space, the presentation of various life stories and a review of the main milestones of the development path. The elements of local government capacities of peripheral small towns in the region are assessed on the basis of operational and efficiency aspects. The lack or reduced mobility of these elements has negative implications on local government functions, the delivery of public services, the availibility of local resources and the vitality of the local economy.

The recently launched Hungarian Village Program categorizing small towns with less than 5,000 inhabitants as villages may fuel further reflections on the development policy and governance relevance of the research. The analysis of developments planned and undertaken in the framework of the project and the monitoring of the implementation of the Modern Villages and Small Towns Programme will constitute the tasks of the next phase of the research.
\end{abstract}

Keywords: urban development, small town, Modern Villages Programme, settlement network

\section{INTRODUCTION}

The analysis of the rural-urban dichotomy, the diverging social characteristics of these distinct types of spatial organization have long attracted academic interest. Imbalances in national urban systems have been widely discussed in regional scientific researches (for example, ESPON, 2005a, 2005b; Gorzelak, 2019; Mezei, 2019). Settlement network analyses have put the urbanrural dichotomy at centre-stage in descriptive and model studies alike (e.g., Kresl, 2012; Woods \& Heley, 2017). The settlement network is characterized by relative stability and long-term evolution, which allows for the conceptualisation of the totality of settlements as the ensemble of spatially differentiated social groups. The role of cities in social reproduction, the 
dissemination of high culture and economic growth is a unique manifestation of the allocation of political power.

Over three-quarters of the European population and two-thirds of the Hungarian population reside in urban areas, while $21 \%$ live in small towns, defined as settlements with a population of 5,000-50,000 inhabitants (Atkinson, 2019). Hungary, alongside Ireland, Lithuania, Luxembourg, Norway and Slovakia belongs to the group of European countries with an overrepresentation of the population living in smaller settlements. The number of cities and the proportion of the urban population have shown an upward trend since 1950. In 1950, the number of settlements with urban status in Hungary was 54, with $36 \%$ of the population living in urban settlements (Hajdú \& Rácz, 2020). The population and number of cities rose significantly between 1988-1990 and 2000-2006, respectively. The breakdown of urban growth across European regions is likely to follow a core-periphery pattern in the future, with peripheral regions facing decline and capital regions seeing an increase in their urban population. All this underlines the importance of the wider regional context that shapes the decline or development of small towns.

\section{URBAN DEVELOPMENT IN EUROPE}

The settlement structure of Central and Eastern European countries has strong historical roots, revealing similar urban development pathways albeit with country-specific factors (Hajdú, Horeczki, \& Rácz, 2017; Enyedi, 2011; Rechnitzer, 2013). These countries with a relatively dense urban network dispose of cca. 5,000 towns with a population of 5,000-50,000 inhabitants that act as economic, social and cultural centres to their region.

Europe has only two global cities (London, Paris) and is distinguished among other continents by its dense network of small towns that play an important role in the urban fabric and contribute to preserving the 'uniqueness' of urban life in Europe (Servillo et al., 2017). An ESPON-research (Servillo et al., 2014) reviewing the role of small towns in Europe pointed to a significant divergence of the performance of regions dominated by smaller settlements in remote areas and in metropolitan areas/urban regions, with the latter recording better performances. The devitalisation of small and medium-sized towns outside major metropolitan areas, aggravated by the reduction of public services is presented as a serious threat to territorial cohesion (Barca, 2012; Demazière \& Sykes, 2021). In a few countries, small and medium-sized towns have become privileged subjects of national urban policies in the post-2010 era. In France, a long-standing preoccupation with territorial equality justified growing government 
interventionism targeting this category of settlements. In Germany, the desertification of towns due to the migration of young people from east to west has put the problem of urban shrinkage into the focus of national-level urban policies from the early 2000s (Heinelt \& Zimmermann, 2021). In the UK, the Government has proposed a new deal for 'left behind towns' as a part of its levelling-up agenda dedicated to rebalancing the UK economy from the Southeast and London (UK2070 Commission, 2020; Tallon, 2021). Barca et al. (2012) emphasized the important contribution of small-and medium-sized towns to balanced spatial development in Europe, increasingly challenged by regional economic differences within and not among countries (Bachtler et al., 2019). More recently, the decoupling of major metropolises and peripheral areas has generated a new geography of discontent, with inner peripheries or 'leftbehind places' demanding increasing policy attention and a reorientation of metropolitanbiased government funding to non-metropolitan areas. The concentration of investments and business activities in major urban centres has eroded the position of small-and mid-sized cities in underdeveloped regions, undermining the EU's polycentric vision of urban development (Egyed \& Rácz, 2020). On the other hand, the literature underlines the role of technology diffusion and urban sprawl as important drivers of deconcentration, decreasing the agglomeration advantages of large cities whilst raising the attractiveness of 'rurbanised' residential zones at the edge of metropolitan regions, i.e. small towns capable of reinventing themselves through residential urbanism.

Eastern European urban systems have been heavily shaped by the shifting of state borders in the past century and the legacy of socialist urban and spatial planning experiences. A review of the status and role of small towns within the settlement network of Poland, the Czech Republic, Slovakia and Romania demonstrates the following country-specific features: in the case of the Czech Republic, peripheral small towns located remotely from big cities perform the function of de facto administrative centres but their economic role is negligible. Small towns in the vicinity of large cities have become integrated into suburbia in the form of sleeping towns. Forecasts concerning the future development of small towns along the River Moravia are largely aligned to macro-regional trends. A demographic transition is underway in the study countries, manifest in the declining proportion of younger population groups, an ageing population, and a reduced size but growing number of individual households. Regional and national development documents for 2014-2020 mention three types of small towns: developing (dynamic), balanced (rather stagnating) and peripheral. The polarization issue in Poland was recently addressed by administrative reforms seeking to bolster the role of small and medium-sized towns facing population decline due to migration targeting large 
agglomerations. Despite the rising level of socio-economic disparities over the last 20 years, Poland has a balanced spatial structure comprising 944 settlements with city/town status, its development is exemplary among Central and Eastern European countries. The economic and social power of large cities (Łódź, Wrocław, Poznań, Gdańsk, Szczecin, Bydgoszcz, Lublin, Białystok, Katowice, etc.) has been consolidated over the past 25 years, infrastructural centers (Warsaw and Katowice, etc.) strived to exploit their locational advantages. As a result of the above reform, in Mazovia, for instance, the massive agglomeration of small towns facilitated their better connection to mainstream economic processes. The restructuring of their economic base has generated opportunities for a large number of small towns to embark on successful development paths, such as Garwolin where the industrial and commercial center provides engineering and transportation services in addition to food processing, clothing and leather industries and the manufacture of furniture and cosmetic products. A peculiar feature of the settlement network in Romania is the massive conversion of rural municipalities into towns under the Communist regime, accounting for cca. a third of the total number of urban settlements (Megyesi \& Péti, 2019; Rácz, 2014; Stănuș et al., 2021). Urban development in Romania is marked by underdevelopment combined with peripherality as the underlying cause of the failure of peripheral local societies to meet the challenges of modernization, and a prevalence of small-town culture and society presenting a unique mixture of traditional and modern elements. The primary goal of small towns is to avoid uniformization and preserve their local assets and traditions. Among the neighbouring countries, in the Transylvanian parts of Romania - extending between the border and the Royal Pass - small town development is a major shaping force on the functioning of society and the economy, apparent in the prevalence of conservative values, the importance of small-town mentality, and economic and political flexibility. The settlement network of Transylvania and Székely Land - similarly to Hungary contains a variety of small towns, e.g. spa towns, sleeping towns, micro-regional towns, etc. In Slovakia, the network of small and medium-sized towns is overshadowed by the BratislavaKošice duality. Urbanization processes in Slovakia point to the strengthening of cities with regional significance and the declining status of small towns (Hajdú, Horeczki, \& Rácz, 2017; Novotný et al., 2019). While the number of small towns with a population below 20,000 increased from 65 to 97 during the decade preceding the regime change, nearly one-third of the population of small towns moved to large cities due to internal migration trends. 


\section{URBAN DEVELOPMENT IN HUNGARY}

The Hungarian urban network showed a marked differentiation between settlements with urban status and urban functions in the pre-World War I era. Based on their number, economic structure, administrative institutions and population, a further 250 settlements - functioning as bottom level urban centres - were added to the list of 131 settlements with urban status registered at the turn of the century. Excessive capital city-centricity and the incompleteness of the network of small and medium-sized towns are persistent features of the contemporary settlement network. As a result of the changes brought about by the Treaty of Trianon the monocephalic pattern of the urban system increased, and regional centres were eliminated as a counterweight to the excessive growth of the capital. The changes equally affected the stock and the network of settlements, the number of settlements with city status shrank from 139 in 1918 to 47 by 1920 . The reorganization of borders modified the structure of the national economy, the transport network and catchment areas as well. The urban network was significantly downsized and showed a lack of catchment areas and a spatially uneven distribution of cities. While no significant changes were detected in the proportion of the urban population, Budapest recorded the most spectacular population growth, and the settlements belonging to the Budapest agglomeration also showed rising population numbers (Enyedi, 2012; Hajdú \& Rácz, 2020). The development of agricultural towns of the Great Plain was stifled during this period, in contrast to industrial cities located in the northern part of the country. The economic potential of agricultural towns was largely exhausted in the post-war years, and as a result of continuous population growth and their failure to undergo economic restructuring, these towns were experiencing growing socio-economic inequalities alongside structural deficiencies (Beluszky \& Sikos, 2020).

Despite the significant territorial losses, the development of the national urban network followed a largely similar trajectory to the pre-war period. Deeply entrenched structural deficiencies and regional inequalities continued to pose a serious challenge, vast territories of the country were still lacking urban clusters. The bottom level of the urban hierarchy comprising of structurally diverse small towns remained under-developed. A defining feature of small town economies was their monofunctionality (transport hub, marketplace, educational center, etc.).

Post-1920, the legal framework of the local government system was fundamentally transformed, virilism began to thrive within legislative authorities (Act XXX of 1929). The term 'town with organized council' was replaced by 'county town' following the abolition of 
town councils, the law lists ten towns with legislative authority; in the meantime, the trend of centralization, i.e. administrative guardianship over the local government system was intensifying (Kajtár, 2016).

In terms of settlement network development, 1950 represents a similar watershed to the Compromise, marking the entry into force of the administrative reform. In tandem with the transformation of the county system, this period saw the beginning of the expansion of the urban network with the numerical rise of cities.

The majority of newly declared towns were service providers to the industrial core, largely impervious to residential needs (Germuska, 2002). The country's small and medium-sized urban network included 106 municipalities at the time. Large municipalities performed largely similar functions to contemporary small towns, and cca. half of the 106 settlements with urban functions were legally categorized as towns. This period is referred to as the cycle of relative deconcentration (Enyedi, 2012) marked by the twin processes of economic recovery and industrial restructuring. Against the backdrop of the general slowdown of urban growth, the expansion of small towns discussed earlier led to rapid population growth boosted by government interventions. The National Concept for Settlement Network Development of 1971 (hereinafter: NCSND) introduced a rigid settlement categorization distinguishing nine categories of settlements. The small towns presented in our study fell into the following three categories: secondary centre, partial secondary centre, lower priority level centre. The urban network perspective of NCSND promoted the development of towns with higher order central functions (Bibó, 1975). By 1980, 18 new towns had emerged in this category of settlements in line with the objectives of NCSND. The population growth of small towns was slow-paced, their institutional network was upgraded as a result of industrial developments, and their regional functions were also strengthened (Kovács, 1980).

By the mid-1980s, the number of settlements converted into towns had reached 50 . The majority of these settlements were developed and well endowed in terms of central institutions. The number of settlements with urban functions and settlements with urban status was largely even. During these years, $60 \%$ of the country's population lived in urban agglomerations. As a distinctive feature of urban development in Hungary the current urban population shows a sevenfold increase compared to the Second World War. However, the contemporary state of Hungarian cities raises a number of questions: do they develop at an adequate speed, are socioeconomic factors the exclusive drivers of urban development, on what basis are city title and city ranking distinguished? 
Table 1 Criteria and regulation of city status in the 20th century

\begin{tabular}{|c|c|}
\hline Historical Overview & Criteria for city status \\
\hline Ereky, I. 1932-36 & $\begin{array}{l}\text { - the competences and organization of the local government are } \\
\text { developed } \\
\text { - } \text { above average population density and size } \\
\text { - } \text { grality economic and cultural life } \\
\text { greater political significance }\end{array}$ \\
\hline Egyed, I. 1938 & $\begin{array}{l}\text { - larger population size - congestion } \\
\text { - economic and cultural hub } \\
\text { - } \text { central role - attractivity } \\
\text { - recognition by the state }\end{array}$ \\
\hline Magyary, Z. 1940 & $\begin{array}{l}\text { - large population size } \\
\text { - } \text { vibrant city life } \\
\text { - heterogenous occupational structure } \\
\text { - } \quad \text { intellectual freedom - individuality }\end{array}$ \\
\hline Csizmadia, A. et al. 1941 & $\begin{array}{ll} & \text { autonomous area } \\
\text { - } & \text { autonomous population } \\
\text { - } & \text { advanced legal organization } \\
\end{array}$ \\
\hline Hajdú, Z. 1993 & $\begin{array}{l}\text { - } \text { normativity } \\
\text { - } \text { individual assessment }\end{array}$ \\
\hline $\begin{array}{l}\text { Statutory decree No. } 9 \text { of } 1954 \text { of the } \\
\text { Council of Presidents }\end{array}$ & - towns with district status \\
\hline $\begin{array}{l}\text { Declaration No. } 23 / 1974 \text {. of the } \\
\text { Ministry of Housing and Urban } \\
\text { Development - Office of Councils }\end{array}$ & $\begin{array}{l}\text { - large village } \\
\text { - } \text { secondary or partial secondary centre pursuant to Government } \\
\text { Decree No. } 1007 / 1971 \text {. (III.16.) } \\
\text { - catchment area with a population of } 30,000\end{array}$ \\
\hline $\begin{array}{l}\text { Directive } 7010 / 1983 \text {. of the Ministry } \\
\text { of Housing and Urban Development }\end{array}$ & $\begin{array}{l}\text { - in view of regional endowments } \\
\text { - individual evaluation }\end{array}$ \\
\hline $\begin{array}{l}\text { Government Decree No. } 321 / 2012 \text {. } \\
\text { (XI. 16.) on the spatial planning } \\
\text { procedure }\end{array}$ & $\begin{array}{l}\text { - population above } 10,000 \text { and showing a steady rise over the } \\
\text { previous five years, } \\
\text { - } \text { population coverage by sewage services min. } 60 \% \\
\text { - level of public utilities at least } 60 \% \\
\text { - min. } 90 \% \text { share of inland paved roads }\end{array}$ \\
\hline $\begin{array}{l}\text { Government Decree No. } 61 / 2015 \text {. } \\
\text { (III. 25.) }\end{array}$ & $\begin{array}{l}\text { - No. } 321 / 2012 \text {. complemented by a quantitative assessment of } \\
\text { regional functions } \\
\text { - min. } 20 \% \text { of local employees commute from another settlement } \\
\text { - min. } 20 \% \text { of municipal budgetary revenues originate from local } \\
\text { business taxes }\end{array}$ \\
\hline
\end{tabular}

Source: own compilation based on Kiss, 1998, 457-459 and the regulations cited above.

The multidimensional definition of cities in Hungary has implications on small towns as well. Although the range of settlements obtaining city status post-1990 has generated much criticism, it has enabled the identification of small towns for which the acquisition of the title represented a breakout opportunity (Gyüre, 2010); in addition, it was intended to reflect the actual development of the settlements. A review of the changing criteria for city status demonstrates the dominance of subjective factors and concepts in the pre-2012 period. The 
precise content of regional functions was not fully clarified, neither were elementary or intermediate functions of settlements delienated, nor the concept of high quality cultural life defined, etc. (see Tab. 1).

As a result of the rate of newly declared towns and decentralized development policy, the density of the Hungarian urban network has increased and significant shifts have occurred in the settlement hierarchy in the Socialist era. Over the past thirty years, the Hungarian network of small towns and settlements with a population below 10,000 in particular have shown a dynamic growth, whereas in the rest of the countries of the region growth was more characteristic to large cities that increased in number and size (Horeczki, 2020, Rechnitzer et al. 2014). By the change of regime, the number of settlements with city rights had risen to 166 , and despite the high proportion of predominantly rural areas, settlements with city rights acted as economic, social, cultural and administrative centres to their respective regions. Currently, $24.4 \%$ of the population resides in cities with less than 20,000 inhabitants and $48.1 \%$ in larger cities.

Figure 1 Proportion of the population of small towns in Hungary, 1990-2019

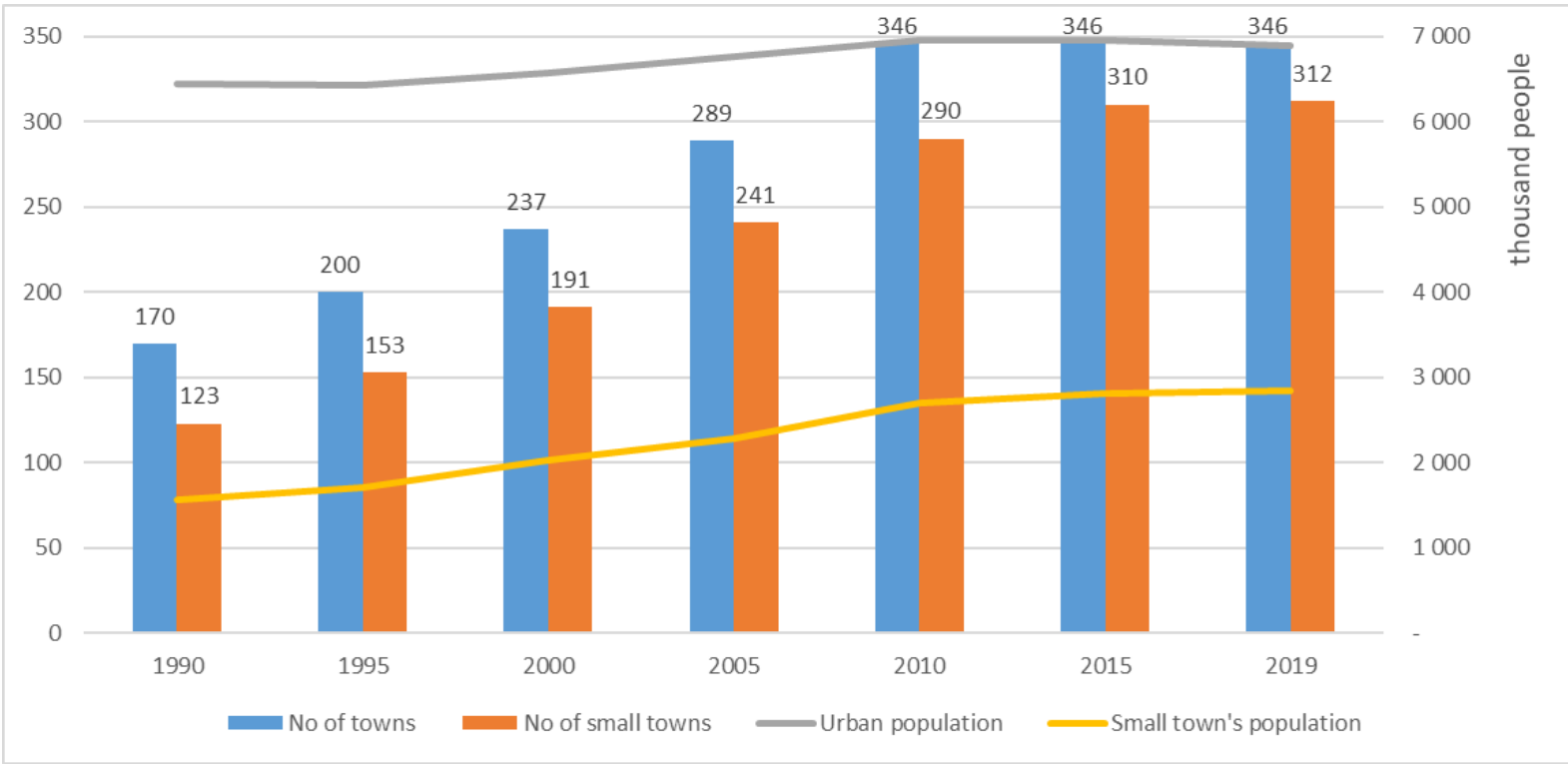

Source: Authors' construction based on CSO data series.

\section{Governance challenges of small towns}

Hungarian small towns present a heterogeneous picture both in terms of their development pathways and their current level of development, underlining the significance of the regional context but also their varying degree of autonomy, i.e. capacity to develop their own sociospatial trajectory (Servillo et al., 2017). The definitional ambiguity surrounding small towns 
has also generated controversies in academic circles. Hence, the harmonization of the system of the allocation of development resources faces serious hurdles. In 2015, the Government launched the Modern Cities Programme with the aim of providing development resources for cities with county rights. According to Viktor Orbán: 'In 2018, it is imperative that we launch the Modern Villages Programme to safeguard the rural way of life and to reverse the migration trend of the population toward big cities.' The pace and absorption of funds shows that following the allocation of development aids to county towns and villages, as of 2020, small towns with a population between 5,000-20,000 are also eligible to apply for funding from the central budget, focusing on competitiveness and job opportunities. However, questions may arise over the issue of settlements with city status and a population below 5,000. What development resources are available for non-county status towns with a population over 20,000 ? Negative trends such as the steady decline and ageing of their population, outmigration due to economic restructuring and a hollowing-out of their centres (offering a limited range of services) have significantly eroded the capacity of small towns to retain their population. This problem should be addressed through targeted support that takes into account the diversity of development trajectories and their variable outcomes. Currently, Hungary has 2,700 settlements with less than 5,000 inhabitants covering approx. three-quarters of its territory. Within the urban network $29.8 \%$ settlements (104) are categorized as small towns with less than 5,000 permanent residents, concentrating 354,030 inhabitants. These elements of the urban network are identified as village towns or titular towns (Beluszky \& Sikos, 2020) devoid of urban character or performing only partial urban functions. The evolution of transport, the level of motorization and consumer demands have boosted the attractivity of bigger cities offering cultural, commercial or other services for rural consumers at the expense of small settlements.

The objective of the Hungarian Villages Programme is to restore the image of the prosperous countryside; aiming to mitigate the negative effects of urbanization. Relying on economic development tools (training and employment support) it emphasizes the protection of cultural heritage and the improvement of the settlement image, it prioritizes social cohesion (through improved security and supporting local communities), furthermore, it promotes the use of digital solutions and technologies with an emphasis on renewable energy sources and egovernment. The development funds will be available for a min. ten-year period, which supposes the urgent launching of more complex, income-generating investments as stated by the president of TÖOSZ. 
Table 2 Settlement network of Hungary (excluding the capital), 2019

\begin{tabular}{|c|c|c|c|c|c|}
\hline Population & Village & $\begin{array}{l}\text { Large village/ } \\
\text { „Nagyközség” }\end{array}$ & Town & $\begin{array}{l}\text { County right } \\
\text { city }\end{array}$ & Total \\
\hline 100 & 136 & & & & 136 \\
\hline $101-$ & 943 & & & & 943 \\
\hline $501-\quad 1,000$ & 670 & & & & 670 \\
\hline $1,001-2,000$ & 597 & 12 & 8 & & 617 \\
\hline $2,001-5,000$ & 351 & 72 & 94 & & 517 \\
\hline $5,001-10,000$ & 8 & 17 & 100 & & 125 \\
\hline $10,001-20,000$ & & 1 & 87 & & 88 \\
\hline $20,001-50,000$ & & & 33 & 5 & 38 \\
\hline $50,001-100,000$ & & & & 11 & 11 \\
\hline $100,001-300,000$ & & & & 7 & 7 \\
\hline
\end{tabular}

Source: Own construction.

Due to the spatial extension of the Hungarian Villages Programme (HVP) to all settlements with less than 5,000 inhabitants, the 104 small towns are currently also eligible to apply for funding. The vast majority of small town residents (94\% of respondents) are well aware that their village is among the potential beneficiaries of HVP funds. The majority of respondents familiar with this fundraising opportunity are employed in the local government sector. $56 \%$ of respondents are women, the majority of whom (67\%) believe that the inclusion of their settlement in the program will entail a loss of their urban status. In their view, the signpost at the outskirts of their settlement indicating their participation in the Hungarian Villages Programme deprives them psychologically of their urban status. As underlined by the responses, the respective small towns left a lot to be desired in terms of their urban functions, physiognomy and service supply, and given their declining and ageing population, their residents consider their future to be very bleak. Local government staff consider the Hungarian Village Program as an opportunity for the revilatization of town centres, construction of sports centres, asphalt works, strengthening the community, etc. The subsidies are destined to improve the population-retention capacity of small settlements, however, no visible economic benefits have been detected so far.

Our review of the first results of the programme clearly indicates that the distribution of resources in the initial period was largely a reflection of the strength of political links. By 2020, the HVP had already started to include applications to support civil society, but this could not compensate for the unevenness of the centralised distribution of resources (Finta, 2020). Based 
on the lists available on the government portal $^{1}$, we found that municipalities with a larger population were better able to take advantage of the programme's support. 259 municipalities with more than 1000 inhabitants won HUF 3,513 million, while 202 municipalities with less than 1000 inhabitants won HUF 2,486 million support. Taking also the beneficiary classification into account, there are 17 municipalities with the most disadvantaged classification, but the number of municipalities receiving aid is zero. The available analysis (Finta, 2019; kormany.hu) report that far fewer applications were received from disadvantaged areas than from their larger (more successful?) counterparts; and that these applications were of much lower quality and rather poorly elaborated. However, these findings are certainly at odds with the underlying objectives of the programme.

\section{CONCLUSION}

Small towns in Europe present a highly heterogeneous picture: their settlement image, physiognomy, social structure, and settlement functions are far from uniform. There are three underlying causes for the existence of 70,000 small towns (with a population below 10,000) in present-day Europe. First, an endogenous driver related to historical factors, i.e. their former market town status. Second, their non-compliance with external requirements: a large number of towns have been declassified due to depopulation, outmigration or functional hollowing-out. The third exogeneous factor is the global urbanization boom triggering successive waves of urbanization post-1990 and post-2000. Small towns play a quintessential role in the European settlement network, concentrating a dominant share of the urban population and settlements. In overall, one-third of the urban population resides in small towns. In many respects, the classification of small towns with a population below 5,000 inhabitants as urban settlements is a mere formality that is justified neither by their urban functions nor their regional role. This is clearly demonstrated by the development funds of the Hungarian Villages Programme that have put these small towns on equal footing with the rest of the settlements with a population below 5,000 inhabitants.

\section{Acknowledgements}

The research of Réka Horeczki was part of project no. 132294 has been implemented with the support provided from the National Research, Development and Innovation Fund of Hungary, financed under the K-19 funding scheme and part of Wacław Felczak Foundation.

The research of Ildikó Egyed was part of the Bolyai Scholarship of the Hungarian Academy of Sciences.

\footnotetext{
${ }^{1}$ https://www.kormany.hu/onkori_dontes.pdf
} 


\section{REFERENCES}

Atkinson, R. (2019). The Small Towns Conundrum: What do we do About Them? Regional Statistics, 9(2), 3-19. DOI:10.15196/RS090201

Bachtler, J., Oliveira Martins, J., Wostner, P., \& Zuber, P. (2019). Towards Cohesion Policy 4.0: Structural Transformation and Inclusive Growth. (Regional Studies Policy Impact Books).

Barca, F., McCann, P., \& Rodríguez-Pose, A. (2012). The case for regional development intervention: place-based versus place-neutral approaches. Journal of Regional Science, 52(1), 134-152. https://doi.org/10.1111/j.1467-9787.2011.00756.x

Beluszky, P., \& Sikos, T. T. (2020). Városi szerepkör, városi rang. Budapest: Dialóg Campus.

Bibó, I. (1975). Közigazgatási területrendezés és az 1971. évi településhálózat fej-lesztési koncepció. Budapest: Magyar Tudományos Akadémia.

Csizmadia, A. et al. (1941). Magyar Városok. Városi és vármegyei szociográfiák 14. Budapest: Globus Nyomdai Müintézet Rt.

Declaration No. 23/1974. of the Ministry of Housing and Urban Development - Office of Councils (,23/1974. ÉVM-MTTH közlemény”) available: http://www.abparancsok.hu/ sites/default/files/parancsok/10_26_5_1974.pdf

Demazière, C., \& Sykes, O. (2021). Acting for cities and towns? The perpetual reinvention of categories and tools of national urban policies in France. In Zimmermann, K., \& Fedeli, V. (Eds.), A Modern Guide to National Urban Policies in Europe. Cheltenham, UK: Edward Elgar Publishing. https://doi.org/10.4337/9781839109058.00007

Directive 7010/1983. of the Ministry of Housing and Urban Development (,7010/1983. ÉVM irányelv") available: https://library.hungaricana.hu/hu/view/DTT_KOZL_TK_ $1983 /$ ?pg=1\&layout $=\mathrm{s}$

ESPON (2005a). Potentials for polycentric development in Europe. ESPON project 1.1.1. Final report. ESPON, Luxembourg.

ESPON (2005b). The Role of Small and Medium-Sized Towns (SMESTO). ESPON project 1.4.1. Final report. ESPON, Luxembourg.

Egyed, I. (1938). A vidéki városi törvényhatóságok jogállása. A korszerü közszolgálat útja 8. Budapest. (manuscript)

Egyed, I., \& Rácz, Sz. (2020). The role of territorial capital in urban renewal in a non-core Central European city. Deturope, 12(3), 108-132.

Enyedi, Gy. (2011). A városnövekedés szakaszai - újragondolva. Tér és Társadalom, 25(1), 519. https://doi.org/10.17649/TET.25.1.1770

Enyedi, Gy. (2012). Városi világ. Budapest: Akadémiai Kiadó.

Ereky, I. (1932-36). Közigazgatási reform és a nagyvárosok önkormányzata I.-II. Statisztikai Közlemények 67. Budapest: Székesfővárosi Házinyomda

Finta, I. (2019). A magyar vidékfejlesztés sikereinek, kudarcainak speciális tényezői. In Farkas, J. Zs. et al. (Ed.), Alföldi kaleidoszkóp - A magyar vidék a XXI. században. Tanulmányok a 70 éves Csatári Bálint köszöntésére (pp. 84-98). Kecskemét: MTA KRTK Regionális Kutatások Intézete.

Finta, I. (2020). A vidékfejlesztés lépcsői a rendszerváltástól napjainkig. Tér és Társadalom, 34(4), 172-177. https://doi.org/10.17649/TET.34.4.3324

Germuska, P. (2002). A szocialista városok létrehozása. Századvég, 2, 49-73.

Gorzelak, G. (2019). Social and Economic Development in Central and Eastern Europe. Stability and Change after 1990. London: Routledge.

Government Decree No. 61/2015. (III. 25.) [“61/2015. (III. 25.) Korm. rendelet”] available: http://www.kozlonyok.hu/nkonline/MKPDF/hiteles/MK15039.pdf 
Government Decree No. 321/2012. (XI. 16.) on the spatial planning procedure [" $321 / 2012$. (XI. 16.) Korm. rendelet a területszervezési eljárásról”] available: https://net.jogtar.hu/ jogszabaly?docid=a1200321.kor

Gyüre, J. (2010). Urbanizáció alulnézetből: Adalékok várossá nyilvánítások belső motivációinak feltérképezéséhez. In Görcs, N. L., \& Pirisi, G. (Eds.), Tér - Tálentum Tanitványok II. (pp. 289-300). Pécs: IDResearch Kft./Publikon.

Hajdú, Z. (1993). A városi jogállás és az urbanizáció történeti alakulása Magyarországon a 18. századtól 1945-ig. Pécs: MTA KRTK Regionális Kutatások Intézete. (manuscript)

Hajdú, Z., Horeczki, R., \& Rácz, Sz. (2017). Changing settlement networks in Central and Eastern Europe with special regard to urban networks. In Lux, G., \& Horváth, Gy. (eds.), The Routledge Handbook to Regional Development in Central and Eastern Europe (pp. 123-140). London-New York: Routledge.

Hajdú, Z. \& Rácz, Sz. (2020): A területi magyar közigazgatás modernizációs kihívásai és reformkisérletei az 1920 utáni korszakban. [The modernization challenges and reform attempts of the Hungarian territorial public administration in the post-1920 era]. Budapest: Nemzeti Közszolgálati Egyetem.

Heinelt, H., \& Zimmermann, K. (2021). National urban policies in a federal system: the case of Germany. In Zimmermann, K., \& Fedeli, V. (Eds.), A Modern Guide to National Urban Policies in Europe. Cheltenham, UK: Edward Elgar Publishing. https://doi.org/10.4337/ 9781839109058.00006

Horeczki, R. (2020). Kisvárosi fejlődési utak. A dél-dunántúli kisvárosok helye és szerepe a térség hosszú távú gazdasági és társadalmi változásaiban. Doctoral Dissertation.

Kajtár, I. (2016). A magyar városigazgatás modernizációja a 19. században. Válogatás a II. Székelyföld Konferencia előadásaiból. available: http://adatbank.transindex.ro/html/ alcim_pdf12669.pdf (2017.09.11.)

Kiss, É. (1998). A várossá nyilvánítás problematikája és a várossá válás jelentősége az önkormányzatok szemszögéböl. Földrajzi Értesitö, XLVII(3), 456-481.

Kovács, T. (1980). Magyarország településhálózata és fejlődésének főbb tendenciái. Statisztikai Szemle, 11, 1061-1080.

Kresl, P. K. (2012). The future of Europe's smaller cities and towns. In Kres1, P. K., \& Ietri, D. (Ed.), European cities and global competitiveness. Strategies for Improving Performance. Cheltenham-Northampton: Edward Elgar.

Magyary, Z. (1940). Mikor újul meg igazán közigazgatásunk? (manuscript).

Megyesi, Z., \& Péti, M. (2019). A comparative analysis of the socio-economic development of Romanian cities and towns inhabited by ethnic Hungarians. Deturope, 11(3), 205-228.

Mezei, C. (2019). Fejlesztési kényszerpályák [The Forced Trajectories of Development]. Budapest: Dialóg Campus Kiadó.

Novotný, L., Kulla, M., Pregi, L., \& Csachová, S. (2019). Economic transformation of postcommunist small towns: Case study of the Lower Spiš region, Slovakia. Deturope, $11(1), 21-41$.

Rácz, Sz. (2014). "New Integration Period?" Changing tendencies of the urban network in South East Europe. Deturope, 6(2), 46-63.

Rechnitzer, J. (2013). Adalékok Kelet-Közép-Európa térszerkezetének felrajzolására. Geopolitika a XXI. században, 3(4), 35-52.

Rechnitzer J., Páthy, Á., \& Berkes, J. (2014). A magyar városhálózat stabilitása és változása. Tér és Társadalom, 28(2), 105-127. https://doi.org/10.17649/TET.28.2.2623

Servillo, L., Atkinson, R., Smith, I., Russo, A., Sykora, L., \& Demazière, C. (2014). Small and Medium Sized Towns in Europe, Final Report. Luxemburg: ESPON 
Servillo, L., Atkinson, R., \& Hamdouch, A. (2017). Small and Medium-Sized Towns in Europe: Conceptual, Methodological and Policy Issues. Tijdschrift voor Economische en Sociale Geografie, 108, (4), 365-379.

Stănuș, C., Pop, D., \& Dragoman, D. (2021). Changing urban system, changing urban policy: Romania since 1989. In Zimmermann, K., \& Fedeli, V. (Eds.), A Modern Guide to National Urban Policies in Europe. Cheltenham, UK: Edward Elgar Publishing. DOI:https://doi.org/10.4337/9781839109058.00014

Statutory decree No. 9 of 1954 of the Council of Presidents ("Elnöki Tanács 1954. 9. sz. törvényerejü rendelet”) available: https://library.hungaricana.hu/hu/view/OGYK_KI1954_06/?pg $=57 \&$ layout $=\mathrm{s}$

Tallon, A. (2021). Places left behind: national urban policy in the UK - from boom to slump and recovery? In Zimmermann, K. \& Fedeli, V. (Eds.), A Modern Guide to National Urban Policies in Europe. Cheltenham, UK: Edward Elgar Publishing. https://doi.org/10.4337/9781839109058.00018

TÖOSZ webpage: http://xn--tosz-5qa.hu/aktualis/hirek/a-toosz-a-mediaban/

UK2070 Commission (2020). Go Big - Go Local. The UK2070 Report On A New Deal For Levelling Up The United Kingdom. 52.

Woods, M., \& Heley, J. (2017). Conceptualisation of Rural-Urban Relations and Synergies. ROBUST receives funding from the European Union's Horizon 2020 research and innovation programme under grant agreement No 727988. https://ruralurban.eu/files/ConceptualisationRuralRelations.pdf

\section{Annexes}

Questions included in telephone survey by questionnaire conducted between 15 September and 5 October 2020:

1. Are you aware of the eligibility of your town for funding from the Hungarian Villages Programme?

2. What is your opinion about the grants of the Hungarian Villages Programme? Reply in your own words.

2a. In case the responses included the term „opportunity”: In what respects do you consider the programme an opportunity? Reply in your own words.

2b. In case the responses included „deprivation”, „loss” or other negative terms: What makes you think that the programme will entail a loss of city status for your settlement? Reply in your own words.

Gender of respondent: male/female

Employed in a Local Government institution? yes/no

Age: Below 50/ above 50 years of age 